\title{
Colligations of Prepositions: Essential Properties of Legal Phraseology
}

\author{
Kamariah Yunus (Corresponding author) \\ Centre of English Language Studies, Faculty of Languages and Communication, Universiti Sultan Zainal Abidin, Gong Badak Campus, Malaysia \\ E-mail: kamariah@unisza.edu.my \\ Su'ad Awab \\ Department of English, Faculty of Languages and Linguistics, Universiti Malaya, Kuala Lumpur, Malaysia \\ Radzuwan Ab Rashid \\ Centre of English Language Studies, Faculty of Languages and Communication, Universiti Sultan Zainal Abidin, Gong Badak Campus, Malaysia
}

Received: 28-05-2016

Accepted: 19-08-2016

Published: 01-11-2016 doi:10.7575/aiac.ijalel.v.5n.6p.199

Advance Access Published: September 2016

URL: http://dx.doi.org/10.7575/aiac.ijalel.v.5n.6p.199

\begin{abstract}
Specialised discourses manifest the organising thoughts of the discourse community that speaks the language. They are formed by a series of interrelated linguistic properties that are joined in sentences by small but very important lexicogrammatical properties - colligations of prepositions. This paper reviewed the linguistic properties that constitute these linguistic patterns (colligations of prepositions) as well as their semantic and pragmatic functions in legal discourse. The literature reveals that prepositions have both the lexical and grammatical statuses. They are prevalent in legal texts, and they play very important role in conveying the thoughts of the discourse community of the law. Proficient linguistic users are marked by having competence of these patterns. Due to the importance of colligations of prepositions in legal discourse, it is recommended that law students and legal scholars be taught colligations of prepositions explicitly rather than learning them implicitly.
\end{abstract}

Keywords: prepositions, colligations, semantic functions, legal discourse, genre

\section{Introduction}

Adult English as Second Language (ESL) law students in tertiary education need to possess collocational competence for their survival in academic and professional worlds. They have to write well-crafted problem question essays often required of them in legal courses, carry out competent legal research, and defend themselves, with sound arguments and reasoning in mock trials, et cetera. Gaining mastery over collocations; that is, having the knowledge of which legal patterns or word combinations sound more natural and appropriate in specific legal texts, genres, and contexts is extremely essential as it will indicate law students' linguistic competence. This ideal notion, however, is not often the case. Many law students, including the subjects in this study, lack colligational competence (fluent use of colligations of prepositions). They may be capable of producing well-formed sentences but their sentences lack naturalness, are nonnative-like, and show a deviation from the spoken and written convention produced by the legal discourse community (Gozdz-Roszkowski, 2004).

Prepositions are small words but they are the most essential words in specialised discourse (Flowerdew, 2009; Hunston, 2008), especially in legal discourse (Bhatia, 1993, 1998; Charrow \& Charrow, 1979; Gozdz-Roszkowski, 2003). They are so prevalent in legal genres for examples acts, statutes, reports, and academic textbooks. They also often appear more than ten times in a sentence. The frequent presence of complex prepositional phrases and single-word prepositions carries a specific reason -they purport to avoid ambiguity and lack of clarity of the text (Bhatia, 1993). Their prevalent features in legal discourse reflect the very characteristic of legal register. It contains lengthy sentences, for example 50 words on average (Danet, 1985). The prominent use of nominalisation, for example to make an amendment to the Constitution instead of to amend the Constitution, a verbal group (Gustafsson, 1984), is another attribute of legal register. The following extract shows the frequent presence of these patterns (10 underlined patterns respectively) in a legal sentence:

Misrepresentations made, or frauds committed, /by agents acting / in the course / of their business / for their principals, have the same effect lon agreements made / by such agents as if such misrepresentations or frauds have been made or committed /by the principals; but misrepresentations made, or frauds committed, lby agents, / in matters which do not fall /within their authority, do not affect their principals.

A study into a group of law students' productions of colligations of prepositional patterns in the problem question essays conducted in the present study showed that they lacked the knowledge of colligations of prepositional patterns, 
thus overlooking the pragmatic functions of the patterns. The patterns produced were mainly inaccurate, thus conveying inaccurate forms and semantic (meanings) and functions of the text. See the extract of a student's essay ${ }^{1}$ below to show the prevalence of the prepositional patterns, as appeared in every single line and underlined, and the erroneous patterns produced (marked $*$ ).

*In situation of where Mr. Chen telephoned Mr. Daud on 22nd accepting the offer but Mr. Daud has insisted that Mr. Chen accept the offer in writing, it falls under acceptance of the proposal/in prescribe manner. The issue is whether the telephoned made by Mr. Chen has a binding contract for his acceptance. In the Contract Acts 1950 S. 7 (b) where to *convert a proposal to promise, the acceptance, stated that the promisee must do as/ according to the promisor demand/of manner/*on acceptance. Since in this case Mr. Daud has asked Mr. Chen to post a letter of acceptance, then Mr. Chen must do as the order. If not, there is no contract between the parties as the acceptance is no absolute. This can be seen *in case of Tinn v. Hoffman.

The student's erroneous pattern can be observed, for example, in the pattern in case of Tinn v. Hoffman (line 8). This is an incorrect usage since the context and semantic function that this student intended to express should be in the following pattern - in the case of which means Tinn $v$ Hoffman's case. The use of the pattern in case of requires a different context, for example in the following sentence: In case of Mr. Tinn's disappearance, the court may postpone the case. The student was clearly confused with the semantic functions of the two patterns. While the complex preposition in the case of signals textual authority (Bhatia, 1998), the pattern in case of expresses probability (Halliday \& Mathiessen, 2004). Due to the importance of these lexico-grammatical patterns, this study aims to review in the body of literature of these essential lexical units, and to uncover the semantic and pragmatic functions of these patterns in legal discourse.

\section{Prepositions}

Prepositions are an important and frequently used category in English (Littlefield, 2006; Sinclair, 1991. They are traditionally categorised as function words, the grammatical items or 'closed system' (Halliday et al., 1964). Several definitions are given for prepositions. A preposition is defined as "a word which relates a substantive, its object, to some other word in the sentence" (Roberts, 1954, p. 222); "a relationship between two entities" (Quirk, Greenbaum, Leech, \& Svartvik, 1972, p. 143); "a word that indicated a relation between the noun and pronoun it governs and another word, which maybe a verb, an adjective or another noun and pronoun" (Huddleston, 1984, p. 336), and "linking words that introduce prepositional phrases" (Biber et al., 2002, p. 28).

\subsection{The Forms of Preposition}

There are two forms of prepositions - simple and complex. According to Essberger (2009), there are more than 150 prepositions in English. 94 of them are simple prepositions and the other 56 are complex prepositions. However, Fang (2000) claims that there are 284 different prepositions in a corpus study of English. 88 of them are simple prepositions and 160 more are complex prepositions. See Table 1 for the list of some simple (single-word) prepositions as adapted from Quirk, Greenbaum, Leech, and Svartvik (1985).

Table 1. Single-word prepositions (adapted from Quirk et al., 1985)

\begin{tabular}{llllll}
\hline about & at & concerning & in & outside & to \\
above & before & considering & inside & over & towards \\
across & behind & despite & into & past & under \\
after & below & down & like & per & until \\
against & beneath & during & near & plus & upon \\
\hline
\end{tabular}

Simple prepositions alone can have more than one meaning. They are polysemous lexical items (Taylor, 1993), and therefore, can be very confusing. The prepositions in, on, at, to, for, of, and from, for example, are prepositions which function to show location, place, direction, and time. An interesting fact about simple prepositions such as on and at is that they have their own patterns, see for example, on Monday and at noon. It is against the convention to replace on Monday with at Monday and at noon with on noon. These are patterns of restriction which occur at a single-word preposition level. Allerton (1982, as cited in Schmitt, 2000) and Carter (1987) consider this patterning as neither grammatical nor lexical collocations but rather the third type of collocation.

Meanwhile, complex prepositions are fixed type of prepositions consisting of multi-word units whose meaning cannot be derived from the meaning of their parts (Jabbour-Lagocki, 1990). They consist of two-word, three-word, and fourword prepositions. Lewis (1993) calls these set of prepositions as polywords while others regard them as structural multi-word sequences or lexical bundles (Biber et al., 1999, 2002) or clusters (Taylor, 1993; Celce-Murcia \& Larsen-

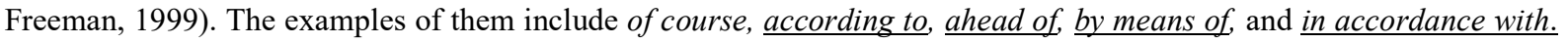

\footnotetext{
1 The Problem Question (PQ) essays consisted of three questions (see Appendix D for the PQ questions). Question no. 1 consisted of three subquestions - $\mathrm{a}, \mathrm{b}$, and c. The essay extract shown as below is from sub-question $\mathrm{b}$ of Question no. 1.
} 
The preposition of in the pattern of course, for example, always collocates with the word course and there is no way that these two words can be separated (Sinclair, 1991). The combination of these two words has become fixed and is regarded as one word or a single preposition (a lexical unit) instead of two or three words. They do not change forms, and are thus fixed collocations. The examples of two-word prepositions are listed in Table 2 and three-word and fourword prepositions in Table 3.

Table 2. Two-word prepositions (adapted from Quirk et al., 1985)

\begin{tabular}{l|l|l|l}
\hline according to & away from & inclusive of & pertaining to \\
\hline ahead of & back of & inside of & preliminary to \\
\hline along with & because of & instead of & preparatory to \\
\hline apart from & close to & irrespective of & prior to \\
\hline as for & contrary to & near to & pursuant to \\
\hline
\end{tabular}

Table 3. Three-word and four-word prepositions (adapted from Quirk et al., 1989)

\begin{tabular}{l|l|l|}
\hline at a cost of & in comparison with & in the case of \\
\hline as opposed to & in compliance with & in the face of \\
\hline at the expense of & in connection with & in the light of \\
\hline at the hands of & in contact with & in the process of \\
\hline at variance of & in contrary to & in view of \\
\hline
\end{tabular}

\subsection{The Status of Prepositions}

As mentioned elsewhere in this study, though prepositions are traditionally assigned as function words or a closed system, preposition is a controversial part of speech, partly due to its 'hybrid' or 'semi-lexical' functions - they have both lexical and grammatical functions (Littlefield, 2011). Some prepositions, unlike other function words such as articles or quantifiers, are considered as taking a lexical category (Grimshaw, 1991) and bear semantic contents (Rauh, 1993, as cited in Littlefield, 2011). In fact, Bordet and Jamet (2010) assert that not only complex prepositions, for example instead of, in view of, or in ignorance of bear the semantic functions or meanings (strong semantic contents), but also simple prepositions, for example about, to, above, at, in, and on. The fact that prepositional items do bear semantic content is also recognised by Halliday (1994). He claims that all prepositional phrases, including the nominal groups containing the preposition of, do have functions. Though the meanings of colligations of prepositions in the present study could be deduced from the co-texts and contexts of the patterns in the concordance lines, Halliday's (1994) and Halliday and Matthiessen's (2004) assignments of the semantic functions of colligations of prepositions were taken as a point of reference in the present study.

\subsection{Types of Colligations of Prepositions}

Single-word prepositions may combine with other word categories to form colligations of prepositions or prepositional phrases. The combinations are less restricted; that is, some word categories may change the form and meaning of each lexical and grammatical item in the combinations, and their meanings can be figured out by their parts. These include the combinations of prepositional items with major lexical categories - nouns, verbs, and adjectives.

Many linguists and lexicographers such as Benson et al. $(1986,1997)$ and Schmitt $(2000)$ call these word combinations as grammatical collocations (colligations). Colligations of prepositions are typical, recurrent combinations of verbal, nominal, or adjectival bases with prepositional collocators (Benson et al., 1997). In the BBI Dictionary of English Word Combinations, such combinations are referred to as a sub-class of grammatical collocations (see categories G1, G5, and G8D in Benson et al., 1997, p. xvi, xviii, xxi). Some examples of colligations of prepositions arranged according to their categories are shown as below:

a. Noun + Preposition

Example: blockade against, apathy towards, damage to

b. Adjective + Preposition

Example: angry at, afraid of, fond of

c. Verb + Preposition

Example: adhere to, consists of, serve as

The Noun + Preposition category was extended in the present study to include the patterns as the following:

a. $\quad \mathrm{NP}+\mathrm{P}+\mathrm{NP}$

Example: the communication of acceptance, manifestation of assent, and instantaneous means of communication 

b. $\quad \mathrm{PP}+\mathrm{NP}$
Example: on behalf of the offeror, in the middle of his reply, in the case of the agreement
c. $\mathrm{VP}($ particle $)+\mathrm{P}+\mathrm{NP}$
Example: take into consideration ${ }^{* 2}$ of the term of contract
d. $\quad \mathrm{VP}($ particle $)+\mathrm{P}+\mathrm{NP}$
Example: come to the knowledge* of the offeror

Benson et al. $(1986,1997)$ disregard the combinations consisting of conjunctions and adverbs plus prepositions, for instance because of, instead of, ahead of, close to, and next to, though they were accepted in this study. Their discussion also does not include noun phrases preceded by prepositions, for example for this reason, in my opinion, and from my point of view, and word clusters such as in lieu of, on account of, and in the name of, though the patterns were employed in this study. They also do not include in their dictionaries the idiomatic expressions, the meanings which cannot be derived from the meanings of their parts, for instance once in a blue moon, pave the way for, or make fun of. Similarly, though derived prepositions and their original patterns, for example regarding and with regard to are not accepted by Benson et al., they were taken into account in the present study.

Phrasal verbs (the combination of V + Particle), however, are considered by Benson et al. (1986, 1997) as prepositional patterns. Phrasal verbs are defined by Celce-Murcia and Larsen-Freeman (1999, p.426) as "made up of two (or more) parts that function as a single verb", or an 'idiomatic expression' (Halliday et al., 1964; Lewis, 2000). They are called phrasal verbs simply because they usually consist of a verb plus an adverb (particle). This particle is different from preposition because it can "fit into more than one category" (Celce-Murcia \& Larsen-Freeman, 1999, p.426). This means that particle can take up several positions - before or after the NP (Noun Phrase). An example of particle coming before the NP is as follows: He called off the meeting. Meanwhile, a particle coming after the NP is exemplified in the following sentence: He called the meeting off. Phrasal verbs may also take specific prepositions to form a unit, for example put up + with, give in + to, and keep up + with.

From the above definitions of colligations of prepositions, we may learn that the potential of two lexical items (a content word and a preposition) to form a single unit called pattern is based on the fact that each of the lexical items in the pattern contributes to its meaning. When this occurs, the patterns are termed 'bound prepositions' (Biber et al., 1999; Essberger, 2009). This indicates that the meaning of the patterns rely on the prepositions which collocate with the content words preceding them. And 'bound prepositions' are to be distinguished from free prepositions, the situation where a preposition does not influence the meaning of the content word coming prior to it. Most of the time, this occurs in situations where verbs are used with prepositions indicating place (e.g., at, in, on), time (e.g., for, during, after), and equipment or companions (e.g., with) (Hunston \& Francis, 2000). These authors exemplified the different usages of the preposition indicating place (at) in the concordance lines in their book. For example, in line 1 of the concordance 'om practice in that England will train at Wembley on the Saturday before', the pattern 'train at' is not a bound preposition but rather a free one. This is in contrast to the pattern 'trained as' in line 4 of the concordance, 'Feb 15), interesting. I trained as a nurse in Brisbane, where it is considered as a single unit, a bound preposition.

\subsection{The Strength of Collocability of Prepositional Patterns}

Prepositions do play their functions as lexical items. This means they carry semantic contents. But when used in patterns (colligations of prepositions), do they also have their semantic part to contribute to the whole pattern? And if they do, which of the two items is stronger? Rankin \& Schiftner (2009) and Sicherl (2004) found that the prepositions used in prepositional phrases are not devoid of content but they do contribute to a certain extent to the colligational base. They even share a similar behavior in terms of the strength of collocability with that of lexical collocations. In other words, the patterns were observed to have a two-way syntagmatic affinity. The stronger leads from the dominant word, for example nominal, verbal, and adjectival to the preposition, while the weaker leads from the preposition to the lexical word. This essentially means that each item in a colligation of prepositional pattern may influence each other though the strength of collocability is unequal.

\subsection{The Semantic-Functions of Prepositional Phrases}

Celce-Murcia and Larsen-Freeman (1999) claimed that "one of the greatest challenges presented by prepositions is their meaning” (p. 404). This is often true since prepositions are polysemous (Taylor, 1993). Many cognitive linguists including Dirven (1993) and Lee (2001) argue that prepositions divide up physical, temporal and abstract space in different ways, and prepositions in different languages might reveal such differences. In order to solve this problem, cognitive linguists use concrete examples rather than the concepts. They use prototypical examples called mental image schemas such as a robin to denote a bird. Therefore, many spatial prepositions (prepositions indicating location, time, duration, and space) are prototyped with objects in space.

Taylor (1993) construes mental image schemas with two entities - the 'figure' (Trajector (TR)) or 'subject' (Lindstromberg, 1998) and the 'ground' (Landmark (LM)). The two terms refer to two entities in a scene or an event. The trajector is a moving or static object (e.g., a cat) whose movement or location is specified with respect to a

\footnotetext{
2 The patterns take into consideration and come to the knowledge (in asterisks) are particle constructions or idiomatic expressions, and they are fixed patterns.
} 
reference point (e.g., a basket), which is the landmark. Figure 1 illustrates a graphic representation of the image schema of $i$, as adapted from Lindstromberg (1998, p.165).

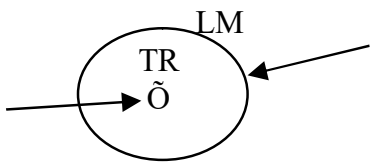

Figure 1. The prototypical figure of in

However, instead of having the spatial and literal meanings for at, as in at the post-office (indicating place) or at noon (indicating time), prepositions also have their extended definitions, as in at work (indicating state), at full speed (indicating manner), and laugh at the funny jokes (indicating cause). This may impose another problem since metaphorical definitions are hard to be schematised. Celce-Murcia and Larsen-Freeman (1999) proposed a series of concentric circles to highlight the physical and mental representations of, for example, preposition at. In their proposal, all the instances of preposition at are bound within an enclosure. The enclosure is more literal and spatial at first (e.g., at + place in at the library, at + time in at 10:00 a.m.) before becoming more abstract and extended (e.g., at + state in at work, at + manner in at full speed, at + cause in laugh at funny jokes). Figure 2 illustrates the concentric circles, as adapted from Celce-Murcia and Larsen-Freeman (1999, p.409).

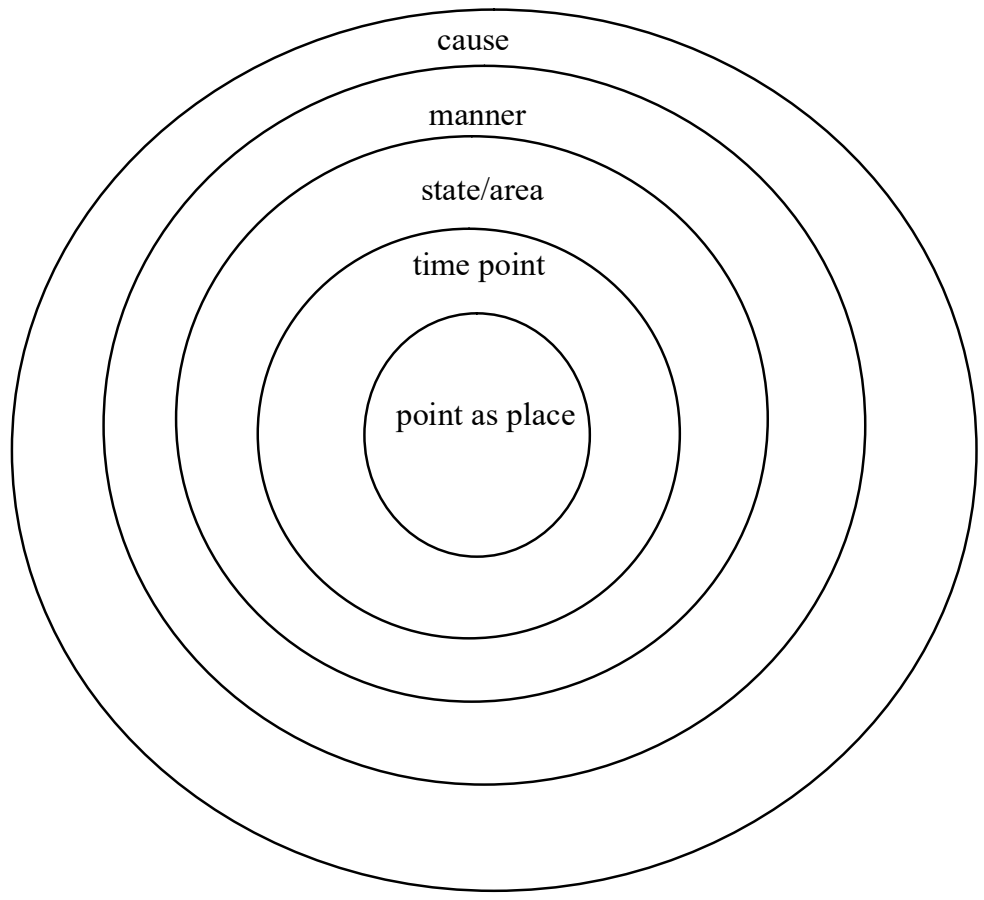

Figure 2. The concentric circle

Meanwhile, Bloor and Bloor (1995), Downing and Locke (2006), Halliday (1994), and Halliday and Matthiessen (2004) are among the proponents of the Systemic Functional Grammar who propose that the fundamental components of meaning of prepositions are their functional components. Prepositional patterns do play their roles in any speech events. They show their communicative functions in 'contexts of situation' or the social functions (Halliday, 1973). The social functions determine " the pattern of language varieties... or registers... of a community or of an individual, ... derived from the range of uses that language is put to in that particular culture or sub-culture" (Halliday, 1973, p.22). This meaning will vary according to specific registers, fields, and text-types. In a Hallidayan transitive clause, it normally voices five choices - the subject, predicate, verb, complement, and adjunct. Prepositional phrases are expressed as circumstantial adjuncts and post-modifiers. Downing and Locke (2006), Halliday (1994); Halliday and Hasan (1985), and Halliday and Matthiessen (2004) propose more than nine main types of circumstantial semantic functions, for example location, direction (path) and goal, extent, manner, cause, contingency, accompaniment, role, matter, and angle. These ranges of meanings were adopted in this current study as a point of reference prior to the students' work with the concordance lines.

\section{Legal Discourse}

In the previous section, we were introduced to the basic concept and aspects of colligations and prepositions - the types of prepositions and their colligations. We were also highlighted to the problems and difficulties the learners had faced in the acquisition of the patterns. We begin this present section by introducing to the readers a brief description of the language of the law (legal English or legalese), and then describing colligations and prepositions in legal context, 
followed by showing examples of law students' problems and difficulties in the acquisition of colligations of prepositions. While spoken discourse is also of major importance, the focus of attention of this present study is written legal genre, in particular, legal academic textbook of law of contract genre.

The term 'legal' simply refers to anything related to law, lawyers, and court. Meanwhile, the term 'discourse' refers to language in use or 'text in context' (Halliday, 1994). The language variation according to use is referred to register (speech style), the variation which is determined by the 'field, 'tenor', and 'mode'. Legal discourse is shaped by the contexts of situation, both the extra-linguistic (the legal discourse community), and linguistic (the lexico-grammatical patterning of legal texts). Legal discourse warrants its status as a sub-language of the LSP due to its restricted expressions and its formal or near-formal written variety (Halliday et al., 1964; Sinclair, 2004a). Danet (1980, 1985) even prefers to label it a 'register' due to this formal and distinctive variety.

\subsection{The Properties of Written Legal Discourse}

Language plays a very critical role in legal discourse. To simply put, law would not exist without language. Law plays two main functions - regulative (to regulate relationships between judicial entities, for example marriage ceremonies and constitutive (to restore), for instance social order between individuals. Besides, there are also numerous genres (defined as a particular language practice, see Swales, 1990) within the field of law itself, for example contract law (the focus of attention of this study), torts law, criminal law, constitutional law, and international law. There are also many varieties of text types within an individual genre itself. For example, within the genre of the law of contract, the text types may include contracts, statutes, rules and regulations, judgements, legal textbooks, journal articles, books of cases, and acts. Legalese is well-known for its conventionalised and distinctive style, full of ritualised and formulaic expressions, as realised in its syntactic and lexical features and formal register, and which makes it hard for laymen to comprehend (Danet, 1980, 1985; Hiltunen, 1990).

The syntactic structure (syntax) of legalese is always characterised as stereotypical and complicated. This is due to the function of legal texts itself - to convey information and concept of the law to readers or clients as clear and precise as possible. Thus, legal sentence structures are usually lengthy (an average of 2.86 clauses per sentence, see Gustaffson, 1975) and highly nominalised (written in a nominal group instead of a verbal group) as in make such provision for the payment instead of provide for the payment. These nominal groups are often featured in noun phrases and colligations of prepositions (Bhatia, 1993; Tiersma, 1999; Vedralova, 2008).

It is also common for a legal sentence to contain more than 55 words on average (twice as many as in scientific English) with many formulaic expressions and common legal vocabulary (Gustafsson, 1975). Another characteristic of legal syntax is high frequency use of passive constructions (Charrow \& Charrow, 1979), usually expressed in prepositional phrases, for example by the majority, by the FIC, and by the authority. The reasons for putting legal sentences into the passive form instead of the active one are to make it more formal. In the case of the absence of agents or no specific agents in a sentence, the passive is the only choice (Danet, 1985). Another characteristic of legal discourse is repetitiveness of several words of the same part of speech. They are referred to as binomials (containing two words), for example goods and materials and multinomials (containing three or more words), for example employer, partner, or agent. They are used as a means of avoiding ambiguous sentences. Besides, legal discourse is a formal register. The formality is shown by its impersonal style as evident from the prevalent use of the third person pronouns in written texts.

Legal lexicon is also distinctive from general English. Alcaraz and Hughes (2002), Gibbons (1994), Melinkoff (1963), Tiersma (1999), and Vedralova (2008) claim that legal vocabulary are prevalent with: (1) technical vocabulary comprising common words, for example consideration, case, and approval, which have become specialised in legal texts; (2) academic vocabulary (the words which appear frequently in academic text), for example relate, evidence, fees, and persistent, and (3) foreign terminologies, for example mens rea, habeous corpus, and ratio decidendi. However, these words and terminology do not come alone in legal texts. They frequently co-occur or combine with other words to form collocations. According to Durrant (2009), the academic texts of specialised disciplines including law texts show a prominent use of colligations of prepositions. The constructions comprise many typical lexical items (high frequency words) with prepositional items such as based on, concerned with, and according to.

These lexical items, which are also defined as 'procedural or enabling vocabulary', enable speakers and writers to combine legal words and terminology into meaningful association (Kjaer, 2007). According to Kjaer (2007: 4), “... collocations with a specialised legal sense are the types of word combinations that are most frequently found in legal texts of all genres." This actually refers to the combination of technical words with other dominant words. One example is the combination of Adjective + Noun as shown in the patterns legal advice, grand jury, and valid contract. Another example is the combination of technical words with grammatical words as appeared in the patterns in consideration of and subject to the approval of. In other words, what makes legal language special is its width association and conceptual density (Harris, 1997). To conclude, both legal vocabulary and syntax are characterised by a heavy use of nominalisation (grammatical metaphor, see Halliday, 1978) and prepositional phrases, the stylistic lexico-grammatical patterning that characterises a 'special register' (Danet, 1985), meriting a specific domain of LSP.

Colligations of prepositions are claimed as pervasive in legal texts (Bhatia, 1993; 1998; Danet, 1980; 1985). Colligations of prepositions are, in fact, of two types. The first type is the combinations of single-word prepositions, for example by, of, and in, and dominant words. They are examples of technical and semi-technical vocabulary manifested in the patterns such as approval of, in consideration of, and relate to. These are restricted collocations since the 
dominant words may allow only a limited combinability with prepositions. The semantic-functions of these words are dependent on prepositional items. Meanwhile, the second type of colligation of preposition is complex prepositional phrases consisting of two-word, three-word, or four-word prepositions, for example in pursuant of, in accordance with, and on the basis of. Though consisting of many words, they bear only a single semantic content. These two types of colligations of prepositional patterns are worth mentioning as they are indeed the most essentials in legal texts functioning as the construction of knowledge (Halliday et al., 1964; Halliday, 1994) and “...the articulation of conceptual relations in legal discourse..." (Jones \& McCracken, 2006, p.17).

Despite the fact that legal discourse is the "highly institutionalised and sometimes ritualised discourse of the law [which] often follows regular patterns" (Gibbons, 2003, p.286), many have claimed that legal phraseology is a branch of study which is under-researched (Gozdz-Roszkowski, 2004; Kjaer, 2007). There are a few studies focusing on binomials, for instance the studies conducted by Danet (1980), Gustaffson (1975), and Melinkoff (1963). However, only a few researchers concentrated in the field of legal colligation especially colligations of prepositions (see GozdzRoszkowski, 2003; 2004; Vedralova, 2008). Lack of research in this area has motivated the present study to concentrate on this aspect of collocation.

\subsection{The Semantic-Functions of Colligations of Prepositions in Legal Discourse}

Beginning with Firth (1951, 1957a, 1957b) who claim that a specialised language has a system of its own, the NeoFirthians, for example Downing \& Locke (2006), Halliday (1994), Halliday and Matthiessen (2004), and Mitchell $(1971,1975)$ further elaborate that any individual units of language like prepositions perform various functions in a clause. For example, prepositions at, in, on, under, and above are used to express location, for to express extent or manner, by, through, with to express sources, and by to express agent. And the functions of these prepositions may differ when used in different contexts especially in restricted languages. For instance, preposition by in the pattern underlined in the following sentences: (1) If it is a mere term of the contract, the non-approval by the Foreign Investment Committee (FIC) of the deal certainly defeats the sale., and (2) ...such misrepresentations or frauds have been made or committed by the principals., signal the function of authority in legal discourse instead of agent , e.g. in the phrases ...claims made by the text... in Information Science and Technology discourse (Fuentes, 2001) or ...the attempt made by the fetus...in the Research Article abstract (Gledhill, 2009; 2011).

Thorne (1997) states that there are a main and two subordinate functions of legal collocations - the main function is referential (to convey information), whereas the subordinate functions are conative (persuasive), and metalinguistic (discussing language itself). Furthermore, in the analysis of complex colligations of prepositions of a corpus of contracts of 300,000 tokens, Gozdz-Roszkowski (2003) found that complex colligations of prepositions performed many textual (text organisers) and referential functions. The examples of colligations of prepositions used as text organisers are in accordance with, subject to the provision, and pursuant to section $X$. Meanwhile, those that signal referential functions include in the presence of, for the benefit of, and on the part of.

Moreover, Gozdz-Roszkowski (2004), in his analysis of a legal contract corpus reported that complex collocations of prepositions containing the word consideration and prepositions, for instance in consideration of, for valuable consideration, and total failure of considerations constitute the constructions found to be dominant in all legal contract genres such as statutes, contract acts, cases, and academic textbooks. Both the patterns in consideration of and for good and valuable consideration, for example, were found to be at precisely the same point in contracts and their function is to introduce the most essential part of any contract.

Bhatia (1998) also observed four major kinds of intertextual devices employing prepositional sequences in a corpus of legislative discourse based on the British Housing Act 1980. Those devices serve the following functions: (1) signalling textual authority (e.g., in accordance with, in pursuance of, by virtue of); (2) providing terminological explanation (e.g., within the meaning of); (3) defining legal scope (e.g., subject to paragraph 11 (2) of Schedule 2 to this Act), and (4) facilitating textual mapping (e.g., specified in section, referred to in subsection from falling within the meaning of). Meanwhile, Vedralova (2008) in the analysis of EU (European Union) legislation corpus of 160, 000 words reported that complex colligations of prepositions did play several roles: (1) addition (e.g., in addition to); (2) exception (e.g., with the exception of); (3) manner (e.g., by means of, on the basis of); (4) identification (e.g., on behalf of); (5) condition (e.g., as regards); purpose (e.g. for the purpose of, with a view to), and reference (e.g., in conformity with, in line with, in accordance with). She also claimed that many of the listed colligations of prepositions in the corpus express reference. In a similar vein, Durrant (2009) in his doctoral study on academic collocations revealed that the first 40 out of 100 academic collocations extracted from the corpus that he developed are colligations of prepositions. These colligations function as textual organisers and reference in all types of academic texts including legal academic texts. To conclude, prepositional sequences or colligations of prepositions do play two major functions in legal discourse - communicative or pragmatic functions and discourse functions.

\subsection{The Essential of Colligations of Prepositions in Legal Discourse}

According to Leckie-Tarry (1993, as cited in Ghadessy, 1993, p.28), collocations are very crucial elements in legal discourse since there is always a "relationship between language function and language form". Akmajian (1995, p. 229) also claims that "one important property of a [legal] sentence is its communicative potential and sentences with different structures often have different communicative functions". Halliday (1970b, 1994) claims that specialised discourse structures (lexico-grammatical items) such as colligations of prepositions represent the construction of knowledge, concepts, and conceptual relations in legal discourse. They are also the organising thoughts in the discourse, and they 
perform various pragmatic functions (Bhatia, 1993, 1998; Gozdz- Roszkowski, 2003, 2004). In other words, the language function expressed in legal discourse is the communication of a systematic representation of carefully defined aspects of the world as seen through the lens of the law (Wei, 2010).

Moreover, "legal language is inextricably intertwined with one particular legal system" (Kjaer, 2007, p.3). From a legal point of view, “...concept formation in a legal system may be analysed by studying the stabilisation and specialisation of legal phraseology, i.e. by means of a discourse analysis of the production, reproduction, and recontextualisation of particular legal phrases that are quoted again and again by legal actors in the discursive flows and genre chains characteristic of law" (Kjaer 1990a; 1992, as cited in Kjaer, 2007, p.3). Different genres do have different collocational patterns and language systems, and the differences in linguistic structures are to be found in different genres because it is the genre that chooses specific structures (Biber, 1988).

Further on, in the case where law students are expected to write texts, fluency and accuracy of expressions are vital. This requires knowing “... whether certain word combinations conform to their standard usage in a field of language, i.e. if they are acceptable by a particular LSP [Legal Specific Purposes] community" (Gozdz-Roszkowski, 2004, p.: 402 ) or not. He also comments that it is typical for law students even at a fairly advanced stage to produce grammatically accurate sentences but they tend to sound unnatural, resulted from the lack of knowledge of words typically combine with other words (collocations). Therefore, knowing legal word combinations and fixed expressions which are recurrent in legal texts "...is considered as a marker of a proficient language user within a particular register" (Gozdz-Roszkowski, 2003, p.4).

\section{Conclusion}

Possessing a large stock of vocabulary knowledge is essential for successful communication in academic setting (Gozdz-Roszkowski, 2004; Kamariah Yunus, Mahani Mohamad, \& Borden Waelateh, 2016; Vedralova, 2008). In cases where English is used as a medium of instruction, students would find it a challenging task both to comprehend the subject contents and instruction if they are not a proficient user of English. Considering the fact that specialised discourses like law contains vast chunks of formulaic expressions, multiword units, nominalizations, and collocations, law authorities may need to integrate these lexical phrases in the law curriculum and syllabuses for the benefits of their students. Explicit rather than implicit teaching of colligations of prepositions should be conducted to achieve this end. In other words, the semantic and pragmatics functions that are expressed in legal phraseology would not be acknowledged completely without exposure to colligations of prepositions.

\section{Acknowledgements}

The authors would like to express their gratitude to the Ministry of Education Malaysia (KPM) and Universiti Sultan Zainal Abidin Malaysia (UniSZA) for funding this research project under SLAB/SLAI Grant Scheme.

\section{References}

Akmajian, A. (1995). Linguistics: An introduction to language and communication. Cambridge, MA: MIT Press.

Alcaraz, E., \& Hughes, B. (2002). Legal translation explained. Manchester: St. Jerome Publishing.

Allerton, D. (1982): Valency and the English verb. London/New York: Academic Press.

Benson, M., Benson, E., \& Ilson, R. (1986). The BBI combinatory dictionary of English: A guide to word combinations. Amsterdam: John Benjamins Publishing Company.

Benson, M., Benson, E., \& Ilson, R. (1997). The BBI dictionary of English word combination (revised ed.). Amsterdam: John Benjamins Publishing Co.

Bhatia, V.K. (1993). Analysing genre: Language in professional settings. London: Longman.

Bhatia, V.K. (1998). Intertextuality in legal discourse. The Language Teacher. Retrieved 12 May 1999, from

http://www.jalt-publications.org/tlt/files/98/nov/Bhatia.html

Biber, D., Johansson, S., Leech, G., Conrad, S., \& Finegan, E. (1999). Longman grammar of spoken and written English. London: Longman.

Bloor, T., \& Bloor, M. (1995). The functional analysis of English. London: Arnold.

Bordet, L., \& Jamet, D. (2010). Are English prepositions lexical or grammatical morphemes? Cercles, Occasional Papers, 1-26. Retrieved 23 February, 2012, from http://www.cercles.com/occasional/ops2010/bordetjamet.pdf

Carter, R. (1987). Vocabulary: Applied linguistic perspectives. London and New York: Routledge.

Celce-Murcia, M., \& Larsen-Freeman, D. (1999). The grammar book: An ESL/EFL teacher's course. Boston: Heinle and Heinle Publishing Company.

Contracts Act 1950 (Act 136) \& Contracts (Amendment) Act 1976 (A329). Batu Caves, Selangor: Penerbitan Akta (M) Sdn. Bhd.

Danet, B. (1980). Language in the legal process. Law \& Society Review, 14(3), 447-564. 
Danet, B. (1985). Legal Discourse. In T. A. van Dijk (Eds.), Handbook of Discourse Analysis (vol . 1, pp. 237-291). London: Academic Press.

Dirven, R. (1993). Dividing up physical and mental space into conceptual catogories by means of English prepositions. In C. Zelinsky-wibbelt (Eds.), Natural language processing: The semantics of prepositions (pp. 73-97). The Hague: Moyten de Gruyter.

Downing, A., \& Locke, P. (2006). English grammar: A university course (2 ${ }^{\text {nd }}$ ed.). London and New York: Routledge.

Durrant, P. (2009). Investigating the viability of a collocation list for students of English for academic purposes. English for Specific Purposes, 28, 157-169.

Essberger, J. (2009). English prepositions listed. Retrieved 12 October 1999, from http://www.my.englishclub.com

Firth, J. R. (1957a). Modes of meaning. In J. R. Firth (Eds.), Papers in linguistics, 1934-1951 (pp. 190-215). London: Oxford University Press.

Firth, J.R. (1957b). A synopsis of linguistic theory, 1930-1955. In J. R. Firth (Eds.), Studies in linguistic analysis (pp. 132). Oxford: Philological Society.

Flowerdew, L. (2009). Applying corpus linguistics to pedagogy: A critical evaluation. International Journal of Corpus Linguistic, 14(3), 393-417.

Fuentes, A. C. (2001). Lexical behavior in academic and technical corpora: Implications for ESP development. Language Learning and Technology, 5(3), 106-129.

Gibbons, J. (1994). Language of the law. London: Longman.

Gibbons, J. (2003). Forensic linguistics: An introduction to language in the justice system. Malden, MA: Blackwell.

Gledhill, C. J. (2009). Colligation and the cohesive function of present and past tense in the scientific research article. In D. Banks (Eds.), Les Temps et les textes de spécialité (pp. 65-84). Paris: L'Harmattan.

Gledhill, C. J. (2011). The 'lexicogrammar' approach to analysing phraseology and collocation in ESP texts, ASp 59, 523.

Ghadessy, M., Henry, A., \& Roseberry, R. (eds.) (2001). Small corpus studies and ELT. Amsterdam: John Benjamins.

Gozdz-Roszkowski, S. (2003). PALC'03 Abstracts from the Fourth International Conference on Practical Applications in Language Corpora. Lódz: Lódz University Press.

Gozdz-Roszkowski, S. (2004). Multi-word lexical units in legal genres: The pedagogic perspective. In B. Lewandowska-Tomaszczyk (Eds.), Practical applications in language and computers (PALC 2003) (pp. 401-413). Frankfurt: Peter Lang.

Grimshaw, J. (1991). Extended projection. Manuscript: Brandeis University.

Gustaffson, M. (1975). Some syntactic properties of English law language. Turku, Finland: University of Turku, Department of English.

Gustaffson, M. (1984). The syntactic features of binomial expressions in legal English. Text, 4(1-3), 123-141.

Halliday, M.A.K. (1970b). Language structure and language function. In J. Lyons (Eds.), New horizon in Linguistics (pp. 140-165). Harmondsworth: Penguin.

Halliday, M.A.K. (1978). Language as social semiotic: The social interpretation of language and meaning. London: Edward Arnold.

Halliday, M.A.K. (1994). An introduction to functional grammar (2 ${ }^{\text {nd }}$ ed.). London: Edward Arnold.

Halliday, M.A.K., \& Hasan, R. (1985). Language, context, and text: Aspects of language in a social-semiotic perspective. Oxford: Oxford University Press.

Halliday, M. A. K., McIntosh, M., \& Strevens, P. (1964). The linguistic sciences and language teaching. London: Longman.

Halliday, M.A.K, \& Matthiessen, C.M.I.M. (2004). An introduction to functional grammar (3 ${ }^{\text {rd }}$ ed.). London: Arnold.

Harris, S. (1997). Procedural vocabulary in law case reports. English for Specific Purposes, 16(4), 289-308.

Hiltunen, R. (1990). Chapters on legal English. Helsinki: Suomalainen Tiedeakatemia.

Huddleston, R. (1984). Introduction to the grammar of English. Cambridge: Cambridge University Press.

Hunston, S. (2008). Starting with small words. International Journal of Corpus Linguistics, 13(3), 271-295.

Hunston, S., \& G. Francis (2000). Pattern grammar: A corpus-driven approach to the lexical grammar of English. Amsterdam and Philadelphia: Benjamins.

Jabbour-Lagocki, J. (1990). Prepositions of position: An analysis for practical application in the classroom. Eric Document Reproduction Service No.: 332509.

Jones, A., \& McCracken, S. (2006). Teaching the discourse of legal risk to finance professionals: Preliminary steps and emerging issues in developing a linguistically scaffolded curriculum. Retrieved 13 February 2010, from http://www.ling.mq.edu.au/about/staff/jones_alan/FV paper 15 Sept 06.pdf 
Kamariah Yunus., Mahani Mohamad., \& Borden Waelateh. (2016). The breadth of receptive vocabulary knowledge among English major university students. Journal of Nusantara Studies, 1(1), 7-17.

Kjaer, A. L (2007). Phrasemes in legal texts. In H. Burger (Eds.), Phraseology: An international handbook of contemporary research (pp. 506-616). Germany: Walter de Gruyter \& Company.

Laufer, B. (2013). Lexical thresholds for reading comprehension: What they are and how they can be used for teaching purposes, Tesol Quarterly, 47(4), 867-872.

Lee, D. (2001). Cognitive linguistics: An introduction. Oxford: Oxford University Press.

Lewis, M. (1993). The lexical approach: The state of ELT and a way forward. London: Language Teaching Productions.

Lewis, M. (2000). Language in the Lexical Approach. In M. Lewis (Eds.), Teaching collocation: Further developments in the Lexical Approach (pp.126-154). Hove: Language Teaching Productions.

Lindstromberg, S. (1998). English prepositions explained. Amsterdam: Benjamin.

Littlefield, H. A. (2011). Lexical and functional prepositions in acquisition: Evidence for a hybrid category. Retrived 22 April, 2012 from http://www.bu.edu/bucld/files/2011/05/29-LittlefieldBUCLD2004.pdf

Mellinkoff, D. (1963). The language of the law. Boston: Little Brown Co.

Mitchell, T.F. (1971). Linguistic 'goings-on': Collocations and other lexical matters arising on the syntagmatic record. Archivum Linguisticum, 2, 35-69.

Mitchell, T.F. (1975). Principles of Firthian linguistics. London: Longmans.

Quirk, R., Greenbaum, S., Leech, G. N., \& Svartvik, J. (1972). A grammar of contemporary English. London: Longman.

Quirk, R., Greenbaum, S., Leech, G. N., \& Svartvik, J. (1985). A comprehensive grammar of the English language (general grammar). Harlow: Longman.

Quirk, R., Greenbaum, S., Leech, G. N., \& Svartvik, J. (1989). A comprehensive grammar of the English language. London: Pearson Education Limited.

Rankin, T., \& Schiftner, B. (2009). The use of marginal and complex prepositions in learner English. In Mahlberg, M., V. González-Díaz, \& C. Smith (Eds.). Proceedings of the Corpus Linguistics Conference, University of Liverpool, 20 23 July 2009. Retrieved 20 February 2012, from http://www.ucrel.lancs.ac.uk/publications/cl2009/.

Rauh, G. (1993). On the grammar of lexical and non-lexical prepositions in English. In C. Zelinsky-Wibbelt (Eds.), The semantics of prepositions: From mental processing to natural language processing (pp. 99-150). Berlin, Germany: Mouton de Gruyter.

Roberts, P. (1954). University grammar. New York: Longmans Group Ltd.

Schmitt, N. (2000). Vocabulary in language teaching. Cambridge: Cambridge University Press.

Sinclair, J. M. H. (1991a). Corpus, concordance, collocation. Oxford University Press: Oxford.

Sinclair, J. M. H. (2004a). Trust the text. In Sinclair, J. M. H. \& R. Carter (Eds.), Trust the text: Language, corpus and discourse (pp. 9-23). London: Routledge.

Swales, J. M. (1990). Genre analysis. Cambridge: Cambridge University Press.

Taylor, J. R. (1993). Prepositions: Patterns of polysemization and strategies of disambiguation. In C. Zelinsk-Wibbelt (Eds.), Natural language processing: The semantics of prepositions (vol. 3) (pp.151-175). The Hague: Mouten de Gruyter.

Thorne, S. (1997). Mastering English language. Basingstoke: Palgrave Macmillan.

Tiersma, P.M. (1999). Legal language. Chicago, Illinois: University of Chicago Press.

Vedralova, L. (2008). Complex repositions in EU legislation and their translation equivalents. Unpublished master's thesis, Masaryk University, Czechoslavakia.

Wei, L. (2010). Specifying context: A way to decoding legal language. The Asian ESP Journal [Special Edition] (pp. 58-68). 